Hydrology and Earth System Sciences, 7(3), 399-410 (2003) C EGU

\title{
Studies of acid deposition and its effects in two small catchments in Hunan, China
}

\author{
Nandong Xue ${ }^{1,2}$, Hans Martin Seip ${ }^{2}$, Bohan Liao ${ }^{1}$ and Rolf D. Vogt ${ }^{2}$ \\ ${ }^{1}$ College of Resources and Environmental Sciences, Hunan Agricultural University, Changsha 410128, P.R.China \\ ${ }^{2}$ Dept. of Chemistry, University of Oslo, P.O.Box 1033, Blindern, 0315 Oslo, Norway \\ Email for corresponding author: ndxue@yahoo.com.cn
}

\begin{abstract}
Acid deposition and its effects were studied by analysing the chemistry in precipitation, stream water, soil water and soils in two catchments in Hunan. One site, Linkesuo (denoted LKS), is on the outskirts of Changsha, the provincial capital of Hunan, the other (Bailutang, denoted BLT) on the outskirts of Chenzhou in southern Hunan. Volume-weighted average $\mathrm{pH}$ values and sulphate concentrations in wet deposition were 4.58 (BLT) and 4.90 (LKS) and $174 \mu \mathrm{mol}_{\mathrm{c}} \mathrm{L}^{-1}$ and $152 \mu \mathrm{mol}_{\mathrm{c}} \mathrm{L}^{-1}$, respectively. Wet deposition of sulphate has been estimated as $4.3 \mathrm{gS} \mathrm{m}^{-2} \mathrm{yr}^{-1}$ and $3.4 \mathrm{gS} \mathrm{m}^{-2} \mathrm{yr}^{-1}$ at BLT and LKS, respectively. Estimates of the corresponding total depositions (dry + wet) are $6.1 \mathrm{gS} \mathrm{m}^{-2} \mathrm{yr}^{-1}$ and $5.3 \mathrm{gS} \mathrm{m}^{-2} \mathrm{yr}^{-1}$. In precipitation and throughfall, sulphate was the major anion and calcium the major cation. In stream and soil water, nitrate was slightly higher than sulphate on an equivalent basis and magnesium $(\mathrm{Mg})$ not much lower than calcium (Ca). Important soil properties, such as soil $\mathrm{pH}$, soil organic matter ( $\mathrm{SOM}$ ) content, exchangeable acidic cations, exchangeable base cations, effective cation exchange capacity (CECe), base saturation (BS), and aluminium (Al) and iron (Fe) pools, were determined for five forest soil profiles (consisting of four horizons) in each of the two catchments. The soils in BLT are generally more acid, have lower BS and higher Al and Fe pools than the LKS soils. The Al- and Fe-pools were generally higher in the topsoils (i.e. the $\mathrm{O}$ and $\mathrm{A}$ horizons) than in deeper soils (i.e. E and B horizons) especially at the most acidic site (BLT). There are significant correlations between Fe-pools and the corresponding Al-pools in both catchments except between the amorphous $\mathrm{Fe}_{\mathrm{ox}}$ and $\mathrm{Al}_{\mathrm{ox}}$. Considering the long-term high deposition of sulphate, there is a risk of future ecological damage due to acidification, especially in the BLT catchment, although vegetation damage has yet to be observed in the catchments. This condition appears to be representative of a large part of Hunan.
\end{abstract}

Keywords: acid deposition, soil acidification, catchment, Al-pools, Fe-pools, Hunan

\section{Introduction}

Acid deposition, associated with sulphur dioxide $\left(\mathrm{SO}_{2}\right)$ and nitrogen oxide $\left(\mathrm{NO}_{\mathrm{x}}\right)$ emissions created during fossil-fuel combustion, gives rise to a serious impact on natural ecosystems. Although $\mathrm{SO}_{2}$ and $\mathrm{NO}_{\mathrm{x}}$ emissions are declining in North America and Europe, they are rising in many developing countries across the world (Amann, 2001). However, damage from acid deposition still occurs in some regions of North America and Europe and may be increasing in other regions, in particular in south-eastern Asia (Kuylenstierna et al., 2001). Much information about effects of acid deposition has been obtained through catchment studies. Most of these are in Europe or North America and include Christophersen et al. (1982); Nilsson (1985); Neal et al. (1990); Probst et al. (1990); Driscoll et al. (1994);
Dambrine et al. (2000); West et al. (2001); Likens et al. 2002). Recently there have also been such studies in China (Larssen et al. 1998, 2001; Zhao et al. 2001; Shao, 2002).

Acid deposition in China, particularly south of the Yangtze, has increased substantially during the last decades. In 2000, 30\% of China was characterised as acid deposition areas (annual volume weighted precipitation $\mathrm{pH}<5.6$ ); in some areas acid deposition levels exceed the environmental damage level) (SEPA, 2000). Hunan is among the provinces in China most seriously affected by acid deposition. Acid rain was first reported in Changsha (the capital of Hunan) in 1972; it has since become one of the most seriously acid rain polluted cities in China, with an average volume weighted precipitation $\mathrm{pH}$ value below 4.5. In 2000, the annual average volume weighted $\mathrm{pH}$ was 3.53 and the acid 
rain frequency (i.e. $\mathrm{pH}<5.6)$ was $90 \%(\mathrm{SEPA}, 2001)$. Fortunately, Chinese public opinion and the authorities have realised the importance of this problem. According to the National tenth five-year Plan for Environmental Protection, the $\mathrm{SO}_{2}$ emissions shall decrease by $10 \%$ from 2000 to 2005 (SEPA, 2002). Total $\mathrm{SO}_{2}$ emissions in China decreased from 1995 to 1999 but have since probably increased ( $\mathrm{Li}$ and Gao, 2002). Furthermore, building of taller chimneystacks to reduce local pollution increases long-range transport and thereby acid deposition in remote regions.

Acid precipitation and its precursors affect human health, materials and ecosystems (Rodhe et al., 1995; SEPA, 2000). While surface water acidification is not thought to be a major problem in China, acidification of soil and soil water may affect terrestrial ecosystems seriously in many areas including parts of Hunan (Chen et al., 1993, 1995; Williams et al., 1995; Larssen et al., 1998; Liao et al., 1997; Zhao et al., 1994; Seip et al., 1999). The soil and soil water in many areas of the province are sensitive to acidification due to low weathering rates (Duan et al., 2002) and medium to small pools of exchangeable base cations (Liao and $\mathrm{Li}$, 1989). Decrease in soil pH due to acid deposition occurs most rapidly when the cation exchange capacity is low and $\mathrm{pH}$ values are intermediate (5-6). Where soils already have a low $\mathrm{pH}$, the change in soil $\mathrm{pH}$ may be small even if the acid deposition is high; instead soil water acidity and aluminium (Al)-concentration may increase. This will generally imply the most serious ecological threat.

Following several research programmes, great progress has been achieved in understanding the soil acidification process in Hunan in recent decades. The studies include responses of Hunan forest soil to acidic input (Liao et al., 1998), mechanisms of sulphate adsorption in red soils in southern Hunan (Chen et al., 1993, 1995), buffering mechanism of Hunan soil (Liao and Li, 1989), and relative sensitivity of Hunan soils to acid deposition (Hao et al., 1999). However, the only other catchment scale studies on acid deposition in Hunan are conducted by the Integrated Monitoring Program on Acidification of Chinese Terrestrial Systems (IMPACTS, 2003). The study site, CaiJiaTang (CJT), is about $150 \mathrm{~km} \mathrm{SW}$ of Changsha (Shao, 2002).

\section{Site descriptions}

Two acid sensitive catchments, Bailutang (BLT) and Linkesuo (LKS), were selected in Hunan province for detailed studies. The province of Hunan is located in the middle reaches of the Yangtze and lies between $108.8^{\circ} \mathrm{E}$ and $114.8^{\circ} \mathrm{E}$ and between $24.6^{\circ} \mathrm{N}$ and $30.5^{\circ} \mathrm{N}$ (see Fig.1). Its total area is $211800 \mathrm{~km}^{2}$. The mountains and hills occupy more than $80 \%$ of the area and more than one-quarter of the terrain lies at a height of more than $500 \mathrm{~m}$. Hunan province has a subtropical monsoon humid continental climate. The annual average temperature is $16-18^{\circ} \mathrm{C}$, the non-frost period lasts for 260-300 days. Annual sunshine is $1300-1800 \mathrm{~h}$, the annual average rainfall is between 1200 and $1700 \mathrm{~mm}$ with most rain in spring and summer. It is one of the rainiest regions in China.

The forested BLT catchment (Fig. 2) is nearly $400 \mathrm{~m}$ a.s.l. at $25.78^{\circ} \mathrm{N}, 113.01^{\circ} \mathrm{E}$ about $20 \mathrm{~km}$ east of Chenzhou. BLT has, on average, 300 frost-free days a year. The annual average temperature is $16.9^{\circ} \mathrm{C}$. The total annual rainfall is $1548 \mathrm{~mm}$ with the maximum precipitation occurring in spring and summer. The area of the catchment is about $0.15 \mathrm{~km}^{2}$. The main tree species are Chinese fir (Cunninghemia lanceolota) and Masson pine (Pinus

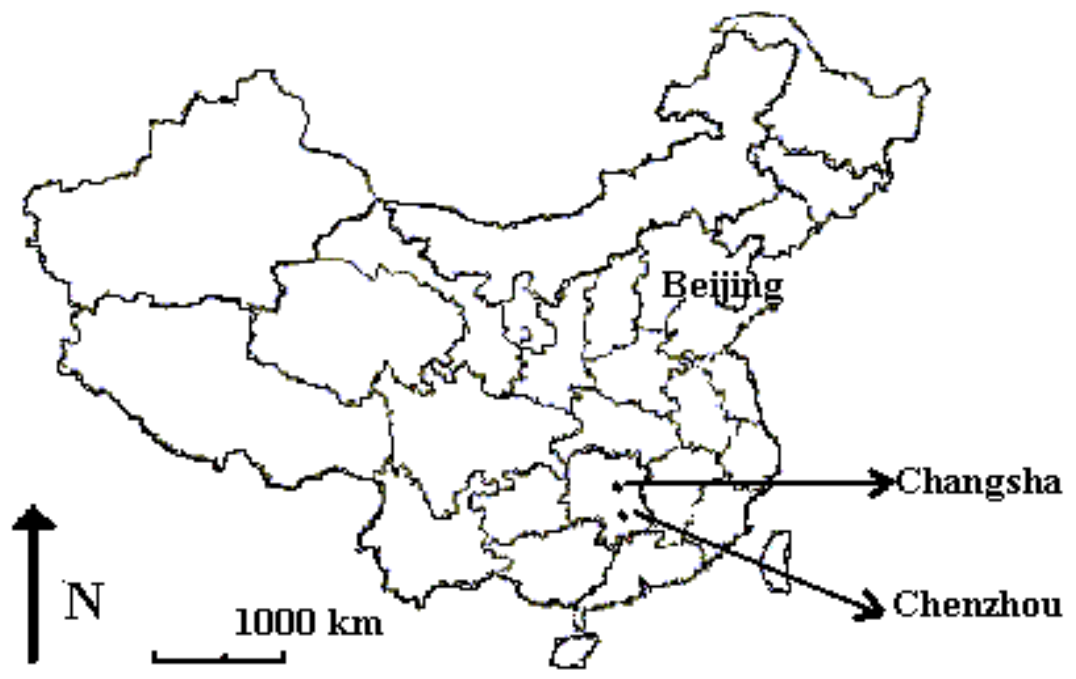

Fig. 1. Map of the Peoples Republic of China with Hunan Province indicated. 

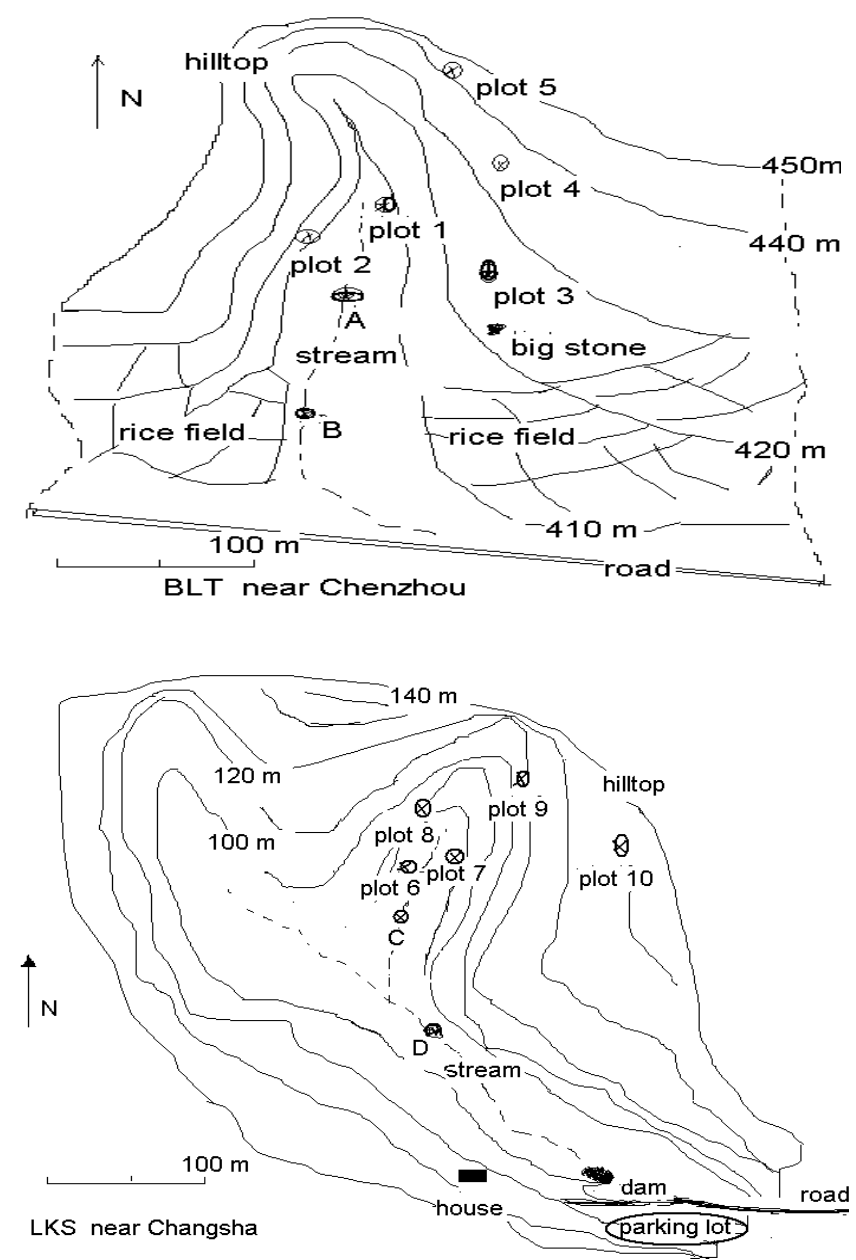

Fig. 2. Topographical map and sampling sites in BLT, near Chenzhou, and in LKS, near Changsha (The plots 1-10 are soil sampling sites; $A, B, C$ and $D$ are the sampling sites for stream water; plots 1 and 7 are soil water sampling sites. The sampling sites for wet deposition, bulk deposition and throughfall were set up near plots 3 and 7)

massoniana) but there is also a range of broad-leaf trees and bushes. The soil is in the Chinese red soil group corresponding to Ferric Acrisol in the FAO system and its parent material is granite. Kaolinite is the dominant clay mineral; there are also small amounts of vermiculite and illite. The catchment was deforested on a large scale in the 1960s. The soil has been practically undisturbed by other land-use activities. Five soil plots were selected for detailed studies (Fig. 2).

Changsha, at $28.2^{\circ} \mathrm{N}, 113.1^{\circ} \mathrm{E}$, about $100 \mathrm{~m}$ a.s.l., has a subtropical climate featuring relatively long hot summers and short cold winters, with annual average temperature of $17.5^{\circ} \mathrm{C}$ and annual average precipitation, $1378 \mathrm{~mm}$. The LKS catchment $\left(0.12 \mathrm{~km}^{2}\right.$, about $100 \mathrm{~m}$ a.s.1, Fig. 2) is some $40 \mathrm{~km}$ east of Changsha. The soil is in the Chinese red soil group corresponding to Ferric Acrisol in the FAO system and its parent material is shale. Kaolinite is the dominant clay mineral; there are also small amounts of hydromica and biotite flakes. The main tree species, Chinese fir (Cunninghemia lanceolota), was planted after deforestation and slash-and-burn cultivation in the late 1960s. Since then, the soil has been practically undisturbed by land-use activities. Five soil plots were selected for detailed studies (Fig. 2).

\section{ANALYSES AND METHODS}

Water was monitored through the two catchments, BLT and LKS. To collect soil water, lysimeters (Vogt et al., 2001), were installed in the A horizon at $20 \mathrm{~cm}$ depth in Plot 1 (BLT) and in plot 7 (LKS) close to the streams (Fig. 2). From 19 June 2000 to 19 June 2002, 54 wet deposition, 24 throughfall, 54 bulk deposition, 13 soil water and 12 stream water samples were collected from BLT and 58 wet deposition, 58 throughfall, 58 bulk deposition and 12 stream water samples were collected from LKS. Additional deposition measurements are available from Hunan Agricultural University (HAU), $10 \mathrm{~km}$ from LKS, but at a lower elevation (about 50 m.a.s.l.) where 58 wet deposition samples and 58 bulk deposition samples were collected during the same period.

The wet-only deposition was collected in plastic buckets placed in the field only during precipitation events while buckets for collecting bulk deposition and throughfall samples were in the field continuously during the monitoring period. Soil water was sampled monthly. However, the lysimeters collected little or no water in dry periods. Stream water was sampled monthly but not in the dry season (usually from July to November). Precipitation volume was measured as soon as rain or snow stopped. All samples were stored in a refrigerator and analysed within a few weeks. The samples were filtered under vacuum through a $0.45 \mu \mathrm{m}$ membrane prior to analysis. The $\mathrm{pH}$ values in water samples were measured with a $\mathrm{pH}$ electrode $(\mathrm{Ag} / \mathrm{AgCl})$ at $20^{\circ} \mathrm{C}$. The cations of calcium $\left(\mathrm{Ca}^{2+}\right)$, magnesium $\left(\mathrm{Mg}^{2+}\right)$, sodium $\left(\mathrm{Na}^{+}\right)$ and potassium $\left(\mathrm{K}^{+}\right)$were analysed by Flame-AAS. Total monomeric $\mathrm{Al}\left(\mathrm{Al}_{\mathrm{a}}\right)$ in soil water and stream water samples was separated into a labile fraction (mainly inorganic spacies, $\mathrm{Al}_{\mathrm{i}}$ ) and a non-labile fraction (mainly organic species, $\mathrm{Al}_{\mathrm{o}}$ ). $\mathrm{Al}_{\mathrm{a}}$ was extracted and determined as described by Barnes (1975) and Driscoll (1984). Concentrations of $\mathrm{Al}_{\mathrm{o}}$ and $\mathrm{Al}_{\mathrm{i}}$ were calculated by the computer program ALCHEMI (Schecher and Driscoll, 1987). Ammonium $\left(\mathrm{NH}_{4}^{+}\right)$was determined spectrophotometrically after reaction with Nessler's reagent $\left(\mathrm{K}_{2} \mathrm{HgI}_{4}\right)(\mathrm{GB} 7479,1989)$; nitrate $\left(\mathrm{NO}_{3}^{-}\right)$was determined by a UV spectrophotometric method 
(Skoog et al., 1998); bicarbonate $\left(\mathrm{HCO}_{3}^{-}\right)$by Gran titration (Gran, 1950, 1952). Sulphate $\left(\mathrm{SO}_{4}^{2-}\right)$ was titrated with a known amount of $0.02 \mathrm{M}$ barium chloride $\left(\mathrm{BaCl}_{2}\right)$ in excess and titrating the surplus $\mathrm{BaCl}_{2}$ with EDTA (di-sodium ethylene- diamine-tetra-acetate solution (APHA, 1985); and chloride $\left(\mathrm{Cl}^{-}\right)$was titrated by $0.1 \mathrm{M}$ silver nitrate $\left(\mathrm{AgNO}_{3}\right)$ with potassium dichromate $\left(\mathrm{K}_{2} \mathrm{Cr}_{2} \mathrm{O}_{7}\right)$ indicator (Department of Chemistry Columbus State University, 2000).

Soils from four generic horizons (O, A, E and B) at the selected plots (Figs. 2 and 3) were sampled at depths given in Table 1. After removing coarse fragments and root debris, the samples were air dried and passed through a $2 \mathrm{~mm}$ sieve prior to analyses. Chemical analyses were conducted partly at the Department. of Environmental Sciences, Hunan Agricultural University, and partly at the Department of Chemistry, University of Oslo.

Soil $\mathrm{pH}_{\mathrm{H} 2 \mathrm{O}}$ was measured using a Ross ${ }^{\circledR} \mathrm{pH}$ electrode (ISO, 1994). Exchangeable cations were extracted using an unbuffered $\mathrm{BaCl}_{2}$ solution (Hendershot and Duquette, 1986). Metal cations $\left(\mathrm{Ca}^{2+}, \mathrm{Mg}^{2+}, \mathrm{Na}^{+}, \mathrm{K}^{+}, \mathrm{Fe}^{3+}, \mathrm{Mn}^{2+}\right.$ and $\left.\mathrm{Al}^{3+}\right)$ in the extracts were determined by ICP-AES (Inductively Coupled Plasma - Atomic Emission Spectrometry). The $\mathrm{pH}$ $\left(\mathrm{BaCl}_{2}\right)$ values measured with a $\mathrm{Ross} \AA \mathrm{pH}$ electrode gave $\mathrm{H}^{+}$in the extracts. The equivalent sum of exchangeable cations gave the effective cation exchange capacity $\left(\mathrm{CEC}_{\mathrm{e}}\right)$. Soil organic matter (SOM) was determined by oxidation with a known amount of $0.8 \mathrm{M} \mathrm{K}_{2} \mathrm{Cr}_{2} \mathrm{O}_{7}$ in excess and titrating the surplus $\mathrm{K}_{2} \mathrm{Cr}_{2} \mathrm{O}_{7}$ with ferrous sulphate $\left(\mathrm{FeSO}_{4}\right)$ solution ( $\mathrm{Lu}, 1999)$.

$\mathrm{Al}$ and Fe-pools include exchangeable $\mathrm{Al}$ and $\mathrm{Fe}\left(\mathrm{Al}_{\mathrm{ex}}\right.$ and $\left.\mathrm{Fe}_{\mathrm{ex}}\right)$, weakly organically bound $\mathrm{Al}$ and $\mathrm{Fe}\left(\mathrm{Al}_{\mathrm{c}}\right.$ and $\left.\mathrm{Fe}_{\mathrm{c}}\right)$, strongly organically bound $\mathrm{Al}$ and $\mathrm{Fe}\left(\mathrm{Al}_{\mathrm{p}}\right.$ and $\left.\mathrm{Fe}_{\mathrm{p}}\right)$ and amorphous and organic $\mathrm{Al}$ and $\mathrm{Fe}\left(\mathrm{Al}_{\mathrm{ox}}\right.$ and $\left.\mathrm{Fe}_{\mathrm{ox}}\right)$. The data for exchangeable $\mathrm{Al}$ and $\mathrm{Fe}$ are generated in the $\mathrm{CEC}_{\mathrm{e}}$ determination described above. $\mathrm{Al}_{\mathrm{c}}$ and $\mathrm{Fe}_{\mathrm{c}}$ were extracted by cupric chloride $\left(\mathrm{CuCl}_{2}\right)$ electrolyte (Jou and Kamprath,

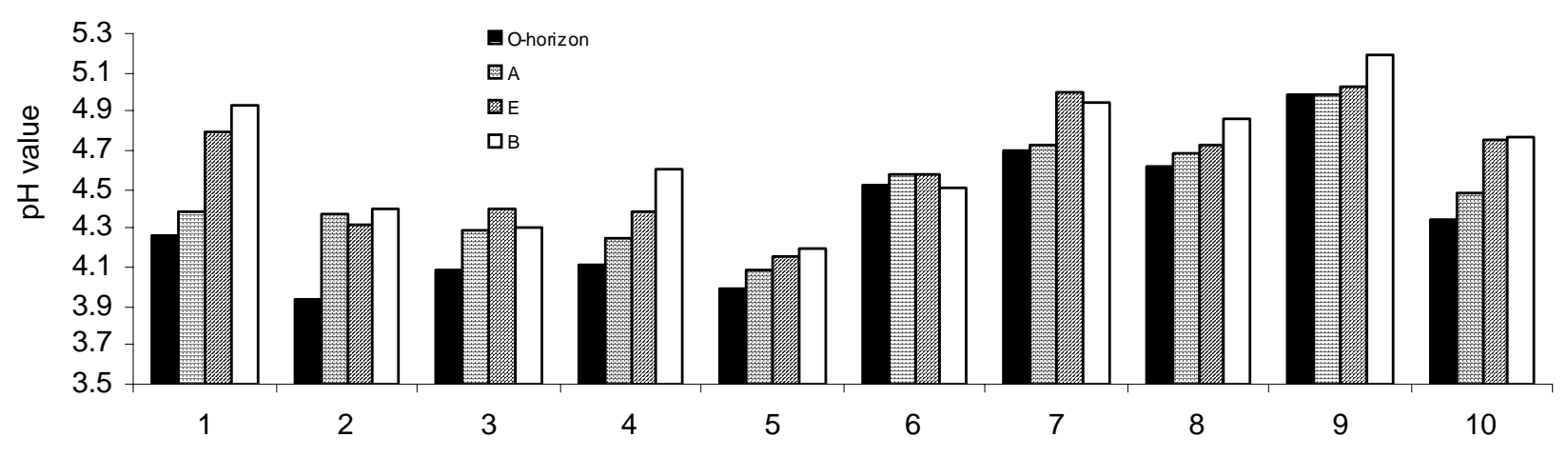

Fig. 3. Soil $\mathrm{pH}$ values (in $\mathrm{H}_{2} \mathrm{O}$ ) found in 4 horizons at the 10 plots.

Table 1. Soil properties and the Al- and Fe-pools (mean values and standard deviations) in soils from the two Hunan catchments

\begin{tabular}{|c|c|c|c|c|c|c|c|c|c|c|c|c|c|}
\hline \multirow[t]{2}{*}{ Horizon } & \multirow{2}{*}{$\begin{array}{l}\text { Depth } \\
(\mathrm{cm})\end{array}$} & \multirow{2}{*}{$\begin{array}{l}C E C e \\
\left(\mathrm{cmol}_{\mathrm{c}}\right. \\
\left.\mathrm{kg}^{-1}\right)\end{array}$} & \multirow{2}{*}{$\begin{array}{l}B S \\
(\%)\end{array}$} & \multirow{2}{*}{$\begin{array}{l}A l S \\
(\%)\end{array}$} & \multirow{2}{*}{$\begin{array}{l}S O M \\
\left(\mathrm{~g} \mathrm{~kg}^{-1}\right)\end{array}$} & \multicolumn{4}{|c|}{ Al-pools $\left(\mathrm{cmol}_{c} \mathrm{~kg}^{-1}\right)$} & \multicolumn{4}{|c|}{$\mathrm{Fe}$-pools $\left(\mathrm{cmol}_{\mathrm{c}} \mathrm{kg}^{-1}\right)$} \\
\hline & & & & & & $\mathrm{Al}_{\mathrm{ex}}$ & $\mathrm{Al}_{\mathrm{c}}$ & $\mathrm{Al}_{\mathrm{p}}$ & $\mathrm{Al}_{\mathrm{ox}}$ & $\mathrm{Fe}_{\mathrm{ex}} \times 1$ & ${ }^{3} \mathrm{Fe}_{\mathrm{c}} \times 10^{3}$ & $\mathrm{Fe}_{\mathrm{p}}$ & $\mathrm{Fe}_{\mathrm{ox}}$ \\
\hline \multicolumn{14}{|l|}{ Site BLT } \\
\hline $\mathrm{O}$ & $0-10$ & $6.2 \pm 1.2$ & $10.6 \pm 4.2$ & $87.1 \pm 2.5$ & $31.4 \pm 9.2$ & $5.4 \pm 1.0$ & $12.3 \pm 1.9$ & $44.9 \pm 14.1$ & $34.5 \pm 8.9$ & $20 \pm 5$ & $50 \pm 13$ & $43.6 \pm 9.8$ & $16.6 \pm 5.5$ \\
\hline A & $10-30$ & $4.4 \pm 0.9$ & $9.6 \pm 2.7$ & $86.4 \pm 4.8$ & $24.9 \pm 8.0$ & $3.9 \pm 0.7$ & $9.2 \pm 1.2$ & $37.6 \pm 11.3$ & $30.1 \pm 6.8$ & $14 \pm 3$ & $20 \pm 4$ & $35.9 \pm 8.6$ & $10.5 \pm 2.7$ \\
\hline $\mathrm{E}$ & $30-45$ & $4.2 \pm 1.6$ & $12.8 \pm 4.0$ & $83.9 \pm 8.0$ & $23.9 \pm 6.9$ & $3.5 \pm 0.8$ & $7.8 \pm 0.9$ & $31.7 \pm 8.1$ & $26.3 \pm 4.2$ & $13 \pm 3$ & $30 \pm 6$ & $28.4 \pm 6.6$ & $10.7 \pm 2.2$ \\
\hline B & $45-75$ & $3.6 \pm 1.4$ & $13.6 \pm 4.6$ & $79.8 \pm 8.5$ & $16.7 \pm 4.2$ & $2.9 \pm 0.5$ & $6.7 \pm 0.6$ & $25.2 \pm 4.8$ & $24.0 \pm 3.0$ & $11 \pm 2$ & $20 \pm 3$ & $18.6 \pm 4.2$ & $7.9 \pm 0.9$ \\
\hline \multicolumn{14}{|l|}{ Site LKS } \\
\hline $\mathrm{O}$ & $0-8$ & $5.1 \pm 0.8$ & $34.9 \pm 10.1$ & $62.8 \pm 12.2$ & $20.1 \pm 4.5$ & $2.8 \pm 0.7$ & $6.3 \pm 1.4$ & $12.7 \pm 4.0$ & $17.2 \pm 4.5$ & $3.4 \pm 0$. & $19 \pm 5$ & $8.0 \pm 2.0$ & $13.2 \pm 4.0$ \\
\hline A & $8-28$ & $4.5 \pm 0.5$ & $29.0 \pm 9.7$ & 64. $4 \pm 9.5$ & $17.4 \pm 3.1$ & $2.7 \pm 0.9$ & $5.9 \pm 1.2$ & $12.7 \pm 3.5$ & $17.0 \pm 3.8$ & $3.3 \pm 0$. & $12 \pm 3$ & $7.5 \pm 1.2$ & $13.7 \pm 2.8$ \\
\hline $\mathrm{E}$ & $28-50$ & $4.4 \pm 0.7$ & $35.7 \pm 16.1$ & $158.7 \pm 15.4$ & $13.6 \pm 2.8$ & $2.4 \pm 0.3$ & $5.6 \pm 0.8$ & $12.2 \pm 2.9$ & $16.9 \pm 2.4$ & $3.2 \pm 0$ & $8 \pm 1$ & $7.6 \pm 1.0$ & $14.1 \pm 2.4$ \\
\hline B & $50-70$ & $4.5 \pm 1.0$ & $32.3 \pm 13.6$ & $662.3 \pm 5.8$ & $12.7 \pm 1.6$ & $2.3 \pm 0.5$ & $5.0 \pm 0.6$ & $10.5 \pm 1.5$ & $15.9 \pm 1.6$ & $3.2 \pm 0$ & $7 \pm 1$ & $5.9 \pm 0.5$ & $13.9 \pm 1.5$ \\
\hline
\end{tabular}

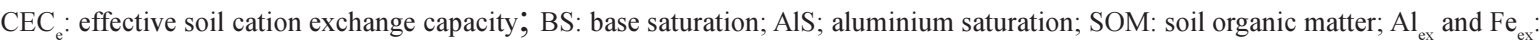
exchangeable $\mathrm{Al}$ and $\mathrm{Fe}, \mathrm{Al}_{\mathrm{c}}$ and $\mathrm{Fe}_{\mathrm{c}}$ : weakly organically bound $\mathrm{Al}$ and $\mathrm{Fe}, \mathrm{Al}_{\mathrm{p}}$ and $\mathrm{Fe}_{\mathrm{p}}$ : strongly organically bound $\mathrm{Al}$ and $\mathrm{Fe}$; $\mathrm{Al}_{\mathrm{ox}}$ and $\mathrm{Fe}$ ox: amorphous and organic $\mathrm{Al}$ and $\mathrm{Fe}$. 
Table 2. Results for calibration samples. $\mathrm{N}$ is number of replicates

\begin{tabular}{|c|c|c|c|c|c|c|}
\hline & $N$ & $N a$ & $K$ & $\mathrm{Ca}$ & $M g$ & $A l$ \\
\hline NIVA $\left(\mathrm{mg} \mathrm{L}^{-1}\right)$ & & 3.93 & 1.50 & 14.6 & 1.49 & 3.26 \\
\hline Calibration on ICP $\left(\mathrm{mg} \mathrm{L}^{-1}\right)$ & 7 & 4.10 & 1.55 & 14.6 & 1.46 & 3.66 \\
\hline Deviation (\%) & & 4.3 & 3.3 & 0.0 & -2.0 & 12.3 \\
\hline Calibration on AAS $\left(\mathrm{mg} \mathrm{L}^{-1}\right)$ & 4 & 4.08 & 1.62 & 13.2 & 1.42 & 3.24 \\
\hline Deviation (\%) & & 3.8 & 8.0 & -9.6 & -4.7 & -0.6 \\
\hline
\end{tabular}

1979). $\mathrm{Al}_{\mathrm{p}}$ and $\mathrm{Fe}_{\mathrm{p}}$ were extracted using a high $\mathrm{pH}(\mathrm{pH}=10)$ sodium pyrophosphate solution (Van Reeuwijk, 1995). Easily available mineral bound $\mathrm{Al}_{\text {ox }}$ and $\mathrm{Fe}_{\text {ox }}$ were extracted with an acid ammonium oxalate $\mathrm{H}_{2} \mathrm{C}_{2} \mathrm{O}_{4} /\left(\mathrm{NH}_{4}\right)_{2} \mathrm{C}_{2} \mathrm{O}_{4}$ solution (McKeague and Day, 1966). Fe and $\mathrm{Al}$ in the extracts were determined by ICP-AES.

House standard water samples with matrix similar to the actual samples were analysed along with the actual samples to account for possible errors and drift in the instrument. On the ICP-AES, the standard sample was run for every 7 th sample and for every 30 th sample on the AAS. Standard calibration samples from NIVA (an ISO-accredited chemical laboratory at the Norwegian Institute for Water Research in Oslo, Norway) for $\mathrm{Ca}^{2+}, \mathrm{Mg}^{2+}, \mathrm{Na}^{+}, \mathrm{K}^{+}$and $\mathrm{Al}^{3+}$ determination were also analysed on both ICP-AES and AAS. The average discrepancies for calibration samples are given in Table 2 . The relative deviations of $\mathrm{Fe}^{3+}$ and $\mathrm{Mn}^{2+}$ determination between ICP-AES and AAS were below 5\%. All the results for other ions were less than one standard deviation from the mean.

In the analyses of soil samples, the intra-laboratory precision was checked by determining values of three sample replicates. The standard deviations (SD) among replicates were below $7.0 \%$. Chemical changes, especially in $\mathrm{NH}_{4}^{+}$ and $\mathrm{NO}_{3}^{-}$, may take place in the field and during transport and storage (Richter and Lindberg, 1988). It took usually two to three hours to transport the samples from the catchment to the refrigerator in the laboratory. Therefore, concentrations for samples analysed immediately after sampling were compared with results for samples stored for three hours at room temperature; the $\mathrm{NH}_{4}^{+}$values were about 7\% lower and the $\mathrm{NO}_{3}^{-}$values about 5.4\% higher than in samples analysed immediately. Storage in a refrigerator for three weeks resulted in values of $\mathrm{NH}_{4}^{+}$and $\mathrm{NO}_{3}^{-}$about 9.5\% lower; this was as if chloroform had been added before storage to prevent biological activity. The changes, while significant, do not distort the general picture and major conclusions. The uncertainties in the analyses were discussed by Liao et al., $(1997,1998)$ and by Larssen et al., 1998).

\section{Results}

\section{PRECIPITATION CHEMISTRY}

The volume-weighted $\mathrm{pH}$ and concentrations of major ions in the precipitation at the two catchments are listed in Table 3. At the BLT catchment, the volume-weighted $\mathrm{pH}$ in wet deposition for the study period was 4.54 . All samples were acidic $(\mathrm{pH}<5.6)$. In the LKS catchment, the volumeweighted $\mathrm{pH}$ for the period was $4.90 ; 80 \%$ of the events, corresponding to about $78 \%$ of the total precipitation amount, were acidic. HAU, located closer to Changsha city centre, experienced considerably lower $\mathrm{pH}$ values and much higher concentrations of $\mathrm{Ca}^{2+}$ and $\mathrm{SO}_{4}{ }^{2-}$ in both wet deposition and bulk deposition.

The sulphate concentration in the wet deposition is much higher than the nitrate concentration both at BLT and at LKS, implying that sulphate is the dominant anion and $\mathrm{SO}_{2}$ the major acid rain precursor. At BLT, the volume-weighted sulphate concentration in wet deposition was $174 \mu_{\mathrm{mol}}$ $\mathrm{L}^{-1}$ for the study period. With an annual precipitation amount of $1548 \mathrm{~mm}$ (based on average values for long-term observations in this area), the corresponding wet deposition was $4.26 \mathrm{gS} \mathrm{m}^{-2} \mathrm{yr}^{-1}$. At LKS, the volume-weighted sulphate concentration was $152 \mu \mathrm{mol}_{\mathrm{c}} \mathrm{L}^{-1}$, and the annual precipitation amount $1378 \mathrm{~mm}$ (also based on long-term observations), giving a wet deposition of $3.37 \mathrm{gS} \mathrm{m}^{-2} \mathrm{yr}^{-1}$. According to the IMPACTS study at the CJT site (Shao, 2002) dry deposition is important in Hunan catchments. Although difficult to quantify, for 2001 it has been estimated roughly. At the IMPACTS CJT catchment the average $\mathrm{SO}_{2}$ concentration was approximately $20 \mathrm{ig} \mathrm{SO}_{2} \mathrm{~m}^{-3}$ (Shao, 2002). Hence, the average $\mathrm{SO}_{2}$ concentrations in the LKS and BLT catchments are also assumed to be $20 \mu \mathrm{g} \mathrm{SO}_{2} \mathrm{~m}^{-3}$. The deposition velocity of sulphur dioxide from the atmosphere onto plant foliage and other solid surfaces varies according to the surface. Zhao et al. (1994) estimated the average deposition velocity to be $0.29 \mathrm{~cm} \mathrm{~s}^{-1}$ in rural areas near Chongqing. However, Larssen et al. (1998) estimated the average deposition velocity to be $0.6 \mathrm{~cm} \mathrm{~s}^{-1}$ in a small catchment near Guiyang. On the assumption that the average 


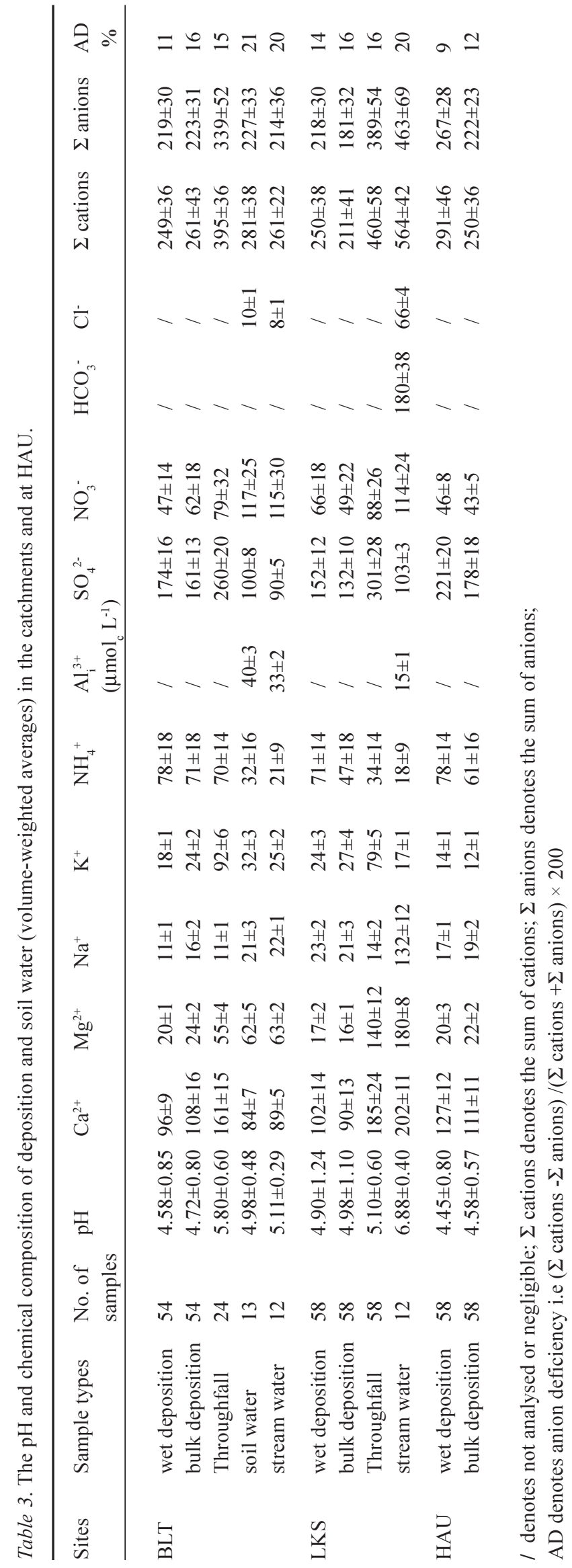

deposition velocity in the two catchments is $0.6 \mathrm{~cm} \mathrm{~s}^{-1}$, the dry deposition of $\mathrm{SO}_{2}$ is $1.88 \mathrm{gS} \mathrm{m}^{-2} \mathrm{yr}^{-1}$, so wet and dry deposition are about $6.1 \mathrm{gS} \mathrm{m}^{-2} \mathrm{yr}^{-1}$ at BLT and $5.3 \mathrm{gS}$ $\mathrm{m}^{-2} \mathrm{yr}^{-1}$ at LKS. Sulphate concentration in throughfall was $268 \mu \mathrm{mol}_{\mathrm{c}} \mathrm{L}^{-1}$ at BLT and $314 \mu \mathrm{mmol}_{\mathrm{c}} \mathrm{L}^{-1}$ at LKS for the monitoring period. Assuming that annual precipitation amounts (1548 $\mathrm{mm}$ at BLT, $1378 \mathrm{~mm}$ at LKS) equal the amounts of throughfall, the $\mathrm{S}$ depositions were $7.8 \mathrm{gS}$ $\mathrm{m}^{-2} \mathrm{yr}^{-1}$ at BLT and $6.6 \mathrm{gS} \mathrm{m}^{-2} \mathrm{yr}^{-1}$ at LKS respectively. Compared with the estimates of dry + wet deposition in the catchments given above, these values are $1.7 \mathrm{gS} \mathrm{m}^{-2} \mathrm{yr}^{-1}$ and $1.3 \mathrm{gS} \mathrm{m}^{-2} \mathrm{yr}^{-1}$ higher, respectively. Throughfall amounts may be less than the annual precipitation but internal Scycling may also contribute. Furthermore, occult deposition (i.e. fog and dew), common in Hunan, was not measured and is not included in the dry + wet values but may well contribute to the throughfall (Zimmermann and Zimmermann, 2002).

The concentrations in precipitation were generally similar to those found in Chongqing (Zhao et al., 1994, 2001), near Guiyang (Larssen et al., 1998) and at the IMPACTS site CJT (Shao, 2002). However, the $\mathrm{NO}_{3}^{-}$concentration in precipitation was high (34 $\mathrm{mmol}_{\mathrm{c}} \mathrm{L}^{-1}$ at CJT), perhaps because of relatively high external inputs of $\mathrm{NO}_{3}{ }^{-}$from the rice field and, at BLT, from traffic on the nearby highway (Fig. 2). However, nitrification of ammonium during sampling, transport and storage may contribute. Among the cations, $\mathrm{Ca}^{2+}$ dominated, both in precipitation and throughfall, and accounted for between 39 and $50 \%$ of the total positive charge. The ionic strength in throughfall was generally higher than that in wet deposition (Table 3) due to evapotranspiration and washing out of dry deposited ions adhering to the vegetation and of ions released from the vegetation (i.e. internal cycling). Due to neutralisation by carbonate ions in the dry deposition, the $\mathrm{H}^{+}$concentration in throughfall is lower than in wet deposition. Also the neutralisation in throughfall can reflect exchange between protons and other cations during foliar leaching. The sum of cations is generally slightly higher than the sum of anions. This anion deficiency (AD) may be due to the neglect of $\mathrm{F}^{-}, \mathrm{I}^{-}, \mathrm{Cl}^{-}$and organic anions.

\section{STREAM WATER AND SOIL WATER IN THE TWO CATCHMENTS}

Concentrations of major anions and cations in stream water and soil water (only BLT) are presented in Table 3. The concentration of $\mathrm{SO}_{4}{ }^{2-}$, which is the main anion in precipitation and throughfall, is lower in stream water and soil water than in precipitation despite substantial evapotranspiration. This implies sulphate retention, 
presumably by adsorption in the soils in the catchments; this sulphate delays acidification of stream water (Galloway et al., 1983; Liao et al., 1994). The nitrate concentration is higher both in stream and in soil water than in wet deposition and bulk deposition. This may be due partly to evapotranspiration and partly to nitrification of ammonium since the ammonium concentration is lower in stream water than in deposition both at BLT and LKS. High nitrate concentrations in the stream despite no clear cutting of vegetation is in contrast to results from a study in a catchment near Guiyang where Larssen et al. (1998) found the nitrate concentration to be high in soil water and very low in the stream. The nitrate concentration in precipitation was lower in the Guiyang catchment, but this is not likely to be the only reason. A possible cause is more chemical transformation in the field under hot conditions (annual average temperature $16.9^{\circ} \mathrm{C}$ ) that increase bacterial activities and thus nitrification processes. (The annual average temperature is $11.7^{\circ} \mathrm{C}$ in the Guiyang catchment (http:// www.impacts.net.cn). Differences in the terrestrial systems and the streams may play a role (Bernhardt et al.,2002), but this has not been analysed.

According to Prietzel and Feger (1992) and Cronan and Grigal (1995), harmful effects are likely in North-American and European terrestrial ecosystems when the $\mathrm{Al} /(\mathrm{Ca}+\mathrm{Mg})$ molar ratio $\left(\mathrm{R}_{\mathrm{CL}}\right)$ is higher than 1.0 in soil water. Despite high $\mathrm{Al}_{\mathrm{i}}$ concentration (weighted average value $40 \mu \mathrm{mol}_{\mathrm{c}}$ $\mathrm{L}^{-1}$, Table 2) in soil water at BLT, the $\mathrm{R}_{\mathrm{CL}}$ is low (i.e. 0.27), so that elevated aluminium concentration in soil water due to acid deposition is no immediate threat. However, only a very limited number of soil water samples are available and more investigations are needed.

Surface water acidification is not a major problem in China except possibly in some small first order streams (Zhao et al., 1994; Seip et al., 1999). In agreement with this, stream water at LKS is close to neutral. However, the $\mathrm{pH}$ in the first order stream water at BLT is considerably lower. Clearly, more studies are needed to establish the extent of surface water acidification in the Changsha region. The high $\mathrm{pH}$ in the stream at LKS shows that the percolating water has been in contact with neutralising soil and/or bedrock.

\section{SOIL CHEMISTRY IN THE TWO CATCHMENTS}

The buffer capacity of the soil plays an important role in ecosystem resistance to acidification. Soil buffer capacity is related to soil acidity, soil organic substances, exchangeable cations, sulphate sorption capacity, as well as aluminium and iron mobilisation. Acid precipitation affects soil properties by increasing acidity and the mobilization of $\mathrm{Al}$ and $\mathrm{Fe}$, and by decreasing base saturation and the rate of organic matter degradation and by changing microbiological activity (NEGTAP, 2001).

Some major soil properties ( $\mathrm{pH}, \mathrm{SOM}, \mathrm{CEC}_{\mathrm{e}}$, base saturation (BS), aluminium saturation (AIS) and $\mathrm{Al}$ and $\mathrm{Fe}$ pools) for ten forest soil profiles (four horizons from each) collected from the two Hunan catchments are given in Figs. 3 and 4 and Table 1 . The soil $\mathrm{pH}$ values in water ranged from 3.94 to 5.19 and BS varied from 6.9 to $51.8 \%$. In general, $\mathrm{pH}$ increases with depth and is lower at BLT than at LKS, especially in the O-horizon (Fig. 3). This is in agreement with the higher AlS and lower BS at BLT than at LKS (Table 1). As commonly found, SOM is highest in the topsoil and generally higher in the more acid BLT than in LKS. The $\mathrm{CEC}_{\mathrm{e}}$ is more variable in the more organic rich BLT than at LKS (Table 1). Generally, exchangeable acidity is higher at BLT than at LKS (Fig.4). This is in agreement with the higher $\mathrm{pH}$ at LKS than at BLT (Fig.3).

Aluminium and iron are the most abundant metallic elements (e.g. $\mathrm{Al}_{2} \mathrm{O}_{3}, 15.9 \% ; \mathrm{FeO}, 9.1 \%$ ) in the continental

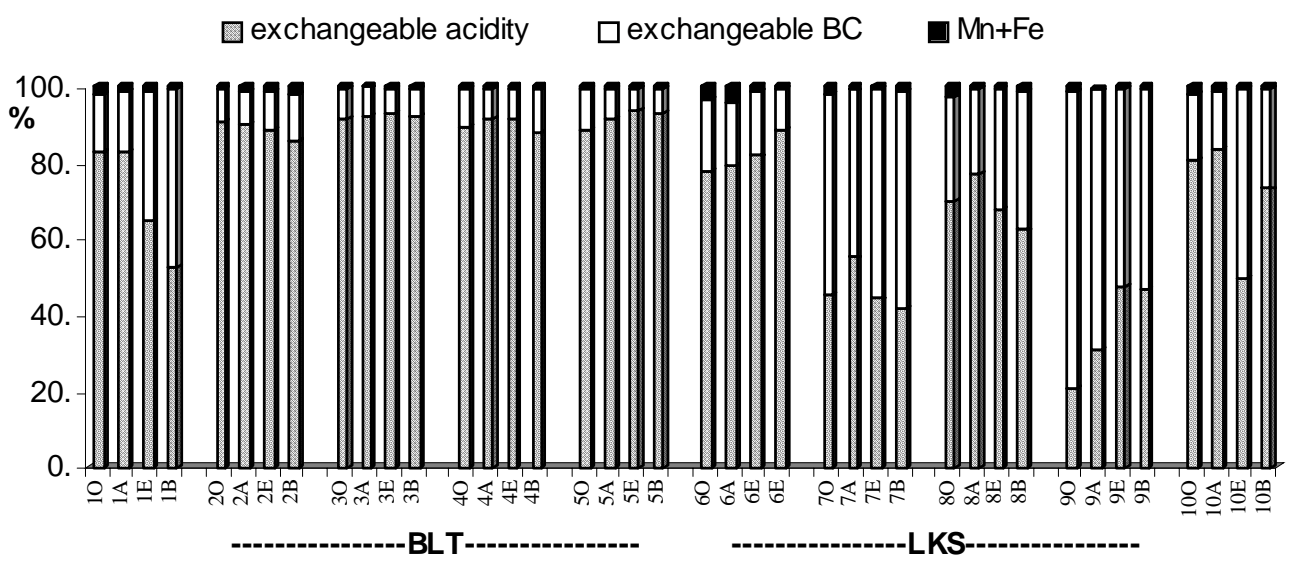

Fig. 4. The composition of the exchangeable cations in soils (The sum of $\mathrm{Al}^{3+}$ and $\mathrm{H}^{+}$gives exchangeable acidity; the sum of $\mathrm{Ca}^{2+}, \mathrm{Mg}^{2+}, \mathrm{K}^{+}$and $\mathrm{Na}^{+}$gives exchangeable $\mathrm{BC}$ ) 
crust (Taylor and McLennan, 1985). They occur in soils in various operationally defined forms. In addition to those mentioned earlier, there are crystalline forms, but these were not determined in this study. Aluminium and iron in these pools are less available although weathering processes in soils and bedrock may make elements from these pools available in the future.

$\mathrm{Al}$ - and $\mathrm{Fe}$-pools are larger (except for $\mathrm{Fe}_{\mathrm{ox}}$ ) in the more acid BLT soils than at LKS (Table 1). The spatial variations in sizes of the Al-pools and Fe-pools are considerable in the two catchments and the ratios $\mathrm{Al}_{\mathrm{p}} / \mathrm{Al}_{\mathrm{ox}}$ and $\mathrm{Fe}_{\mathrm{p}} / \mathrm{Fe}_{\mathrm{ox}}$ are very different at the two sites.

Generally one would expect the easily available mineral bound $\mathrm{Al}$ and $\mathrm{Fe}$ pools $\left(\mathrm{Al}_{\mathrm{ox}} \& \mathrm{Fe}_{\mathrm{ox}}\right)$ to be larger than the amount of $\mathrm{Al}$ and $\mathrm{Fe}$ strongly bound to organic matter $\left(\mathrm{Al}_{\mathrm{p}}\right.$ $\& \mathrm{Fe}_{\mathrm{p}}$ ), i.e. $\mathrm{Al}_{\mathrm{p}} / \mathrm{Al}_{\mathrm{ox}}$ and $\mathrm{Fe}_{\mathrm{p}} / \mathrm{Fe}_{\mathrm{ox}}$ less than unity, because the former comprises both organically bound and amorphous $\mathrm{Al}(\mathrm{Fe})$. However, an $\mathrm{Al}_{\mathrm{p}} / \mathrm{Al}_{\mathrm{ox}}$ ratio greater than unity may be found at sites with highly weathered soils as seen for BLT. The different ratios between BLT and LKS are due to much larger $\mathrm{Al}_{\mathrm{p}}$ and $\mathrm{Fe}_{\mathrm{p}}$ values at BLT (the values correlate well with $\mathrm{SOM}$ ) while $\mathrm{Al}_{\text {ox }}$ and $\mathrm{Fe}_{\mathrm{ox}}$ are more similar at the two sites. Liao et al. (1998) found ratios above one in soils from Chongqing (at Nanshan), Guiyang suburbs and in Hunan (at Huitang). Furthermore, Merino et al. (1994) reported that $\mathrm{Al}_{\mathrm{p}}$ exceeded $\mathrm{Al}_{\mathrm{ox}}$ in some soils in Spain.

$\mathrm{Al}_{\text {ex }}$ ranges from $1.46 \mathrm{cmol}_{\mathrm{c}} \mathrm{kg}^{-1}$ in a subsoil horizon to $6.90 \mathrm{cmol} \mathrm{kg}_{\mathrm{c}}^{-1}$ in an organic soil horizon. $\mathrm{Al}_{\mathrm{c}}$ is between 2.0 and 4.5 times $\mathrm{Al}_{\mathrm{ex}}$, while $\mathrm{Al}_{\mathrm{p}}$ is between 1.8 and 5.5 times $\mathrm{Al}_{\mathrm{c}}$. The sizes of the Al-pools in the soils in the two catchments are in the same range as in the acidic forest soils in Chongqing and Guiyang (Liao et al., 1997) and in acidic forest soils in Europe and North America (Koptsik and Mukhina, 1995; Koptsik and Koptsik, 1995; Koptsik and
Silaeva, 1996; Matzner and Prenzel, 1992; Dahlgren and Walker, 1993; Berggren and Mulder, 1995). The concentration of exchangeable Fe is low, which may limit the availability of this important plant nutrient (Wang et al., 1989). However, Fe in less available pools is abundant. Because there are significant correlations between Fe-pools and Al-pools (Fig. 5), it seems likely that a large release of available nutritional $\mathrm{Fe}$ will be accompanied by a high release of toxic Al.

\section{Discussion}

\section{ASSESSMENT OF PRESENT SOIL STATUS AND POTENTIAL FUTURE SOIL ACIDIFICATION FOR THE TWO SMALL CATCHMENTS}

Soil acid status and potential acidification may be assessed by $\mathrm{pH}, \mathrm{CEC}_{\mathrm{e}}$, BS and exchangeable aluminium. Table 4 lists the soil acidity classification based on these parameters as suggested in SwEPA (2000). The classification applies to soil samples taken from the top horizon in mature forest soil.

Table 4. Soil acididity of present soil status and potential future soil acidification for the two small catchements

\begin{tabular}{lllcc}
\hline Class & Acidity & $\mathrm{pH}_{\mathrm{H} 2 \mathrm{O}}$ & $\begin{array}{l}\text { Effective base } \\
\text { saturation (\%) }\end{array}$ & $\begin{array}{l}\text { Exchangeable } \\
\text { aluminim } \\
\left(\mathrm{cmol}_{\mathrm{c}} \mathrm{kg}^{-1}\right)\end{array}$ \\
\hline $1-2$ & Low & $>5.5$ & $>50$ & $<0.9$ \\
3 & Moderate & $4.4-5.5$ & $10-50$ & $0.9-3$ \\
4 & High & $4.0-4.4$ & $6-10$ & $3-3.6$ \\
5 & Very high & $<4.0$ & $<6$ & $>3.6$ \\
\hline
\end{tabular}
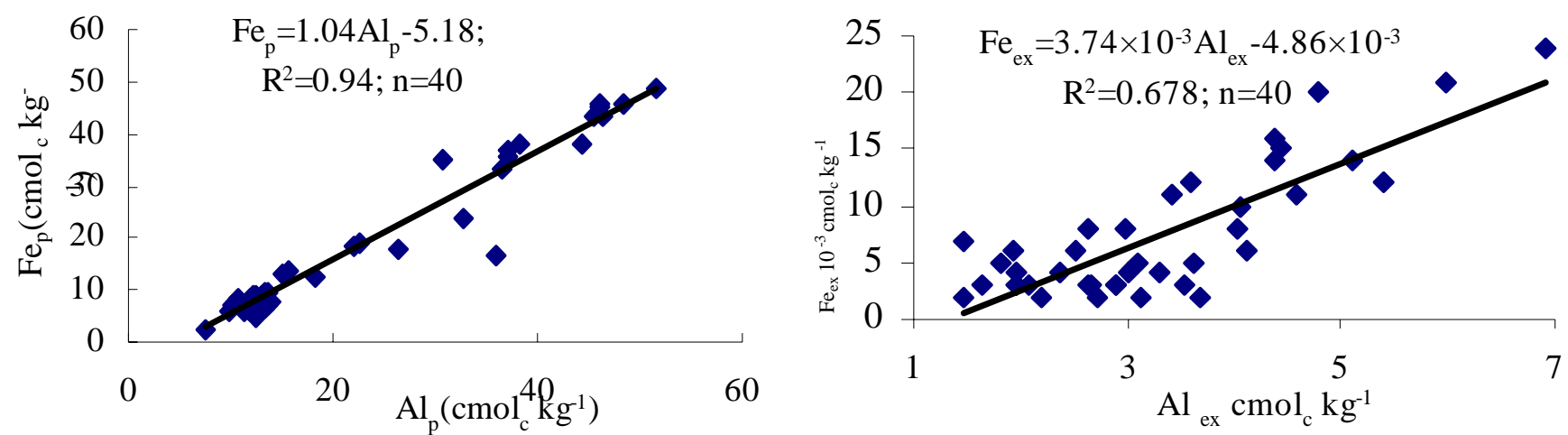

Fig. 5. Relationships between $\mathrm{Fe}_{p}$ and $\mathrm{Al}_{p}$ and between $\mathrm{Fe}_{e x}$ and $\mathrm{Al}_{e x}$. Both correlations are significant with $\mathrm{p} \leq 0.001$. 


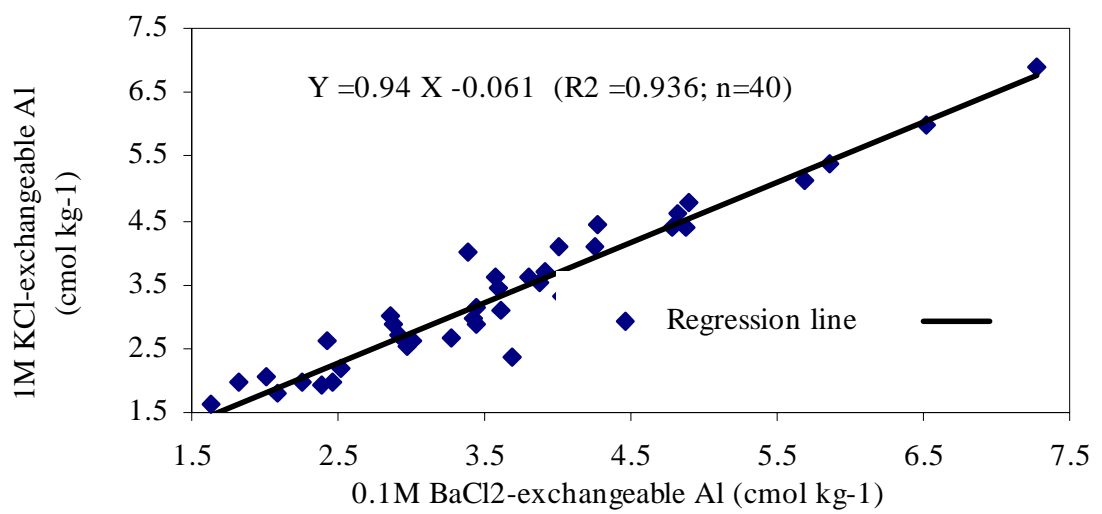

Fig. 6. Comparison of exchangeable aluminium extracted by $1 \mathrm{M} \mathrm{KCl}$ and by $0.1 \mathrm{M} \mathrm{BaCl}{ }_{2}$ ( $Y$ denotes $\mathrm{Al}$ values with $1 \mathrm{M} \mathrm{KCl}$ and $\mathrm{X}$ denotes $\mathrm{Al}$ values with $0.1 \mathrm{M} \mathrm{BaCl}_{2}$ )

The soil is assigned to the acidity class indicated by its $\mathrm{pH}$ value if at least one of the other two parameters falls into the same class. If two other parameters fall into a higher or lower class, the classification is adjusted one step up or down, accordingly. A possible problem in applying the scheme is that $1 \mathrm{M} \mathrm{KCl}$ extraction was recommended to determine the exchangeable aluminium (Lu, 1999), while $0.1 \mathrm{M} \mathrm{BaCl}_{2}$ extraction was used in this study as requested in the IMPACTS project manual (Vogt et al., 2001). Therefore, values obtained with the two methods were compared (see Fig. 6). Although the exchangeable aluminium is higher when extracted with $1 \mathrm{M} \mathrm{KCl}$ rather than with $0.1 \mathrm{M} \mathrm{BaCl}_{2}$, the difference is small and does not affect the classification.

The relevant parameters and soil acidity classification are listed in Table 5. Exchangeable Al was calculated by averaging exchangeable Al values for the topsoils from all sampling plots. The soil at BLT is thereby classified as having high acidity (class 4), while LKS is considered to be moderately acid (class 3 ).

The SwEPA scheme does not include all relevant factors and it may be useful to supplement it with the sensitivity scheme proposed by Tao and Feng (2000), who suggested that the relative sensitivity be determined by identifying a limited number of variables such as bedrock lithology, soil type, land cover and moisture profit and loss. These variables are merged into a small number of categories to which weights are assigned. Combining the four factors and their weights, five relative sensitivity classes $(0-1$, least; 2 , slightly; 3, medium; 4, high; 5-6, most) were given by Tao

Table 5. The relevant parameters and soil acidity classification

\begin{tabular}{llllc}
\hline Catchments & $p H_{H 2 O}$ & $\begin{array}{l}\text { Effective } \\
\text { base saturation (\%) }\end{array}$ & $\begin{array}{l}\text { Exchangeable } \\
\text { aluminium }\left(\mathrm{cmol}_{c} \mathrm{~kg}^{-1}\right)\end{array}$ & Class \\
\hline BLT & 4.2 & 10.0 & 5.34 & 4 \\
LKS & 4.5 & 34.8 & 2.90 & 3 \\
\hline
\end{tabular}

Table 6. Factors and their weights in the sensitivity scheme proposed by Tao and Feng (2000).

\begin{tabular}{lll}
\hline Factors (weights) & BLT (weights) & LKS (weights) \\
\hline Rock Type (1) & Granite (1) & Shale (0) \\
Soil type (1) & Red earth (1) & Red earth (1) \\
Land cover (2) & Coniferous forest (1) & Coniferous forest (1) \\
Moisture profit and loss (2) & $300-600 \mathrm{~mm} \mathrm{yr}^{-1}(0.5)$ & $300-600 \mathrm{~mm}^{-1}(0.5)$
\end{tabular}

Moisture profit and loss was calculated as precipitation minus potential evapotranspiration. 
Table 7. Long-term risk of damage from soil acidification

\begin{tabular}{llll}
\hline \multirow{2}{*}{ Acidity Class } & \multicolumn{3}{c}{ Dewosition $\left(\mathrm{g} \mathrm{S} \mathrm{m}^{-2} \mathrm{yr}^{-1}\right)$} \\
& $<0.25$ & $\begin{array}{l}\text { Moderate } \\
0.25-1.2\end{array}$ & High \\
& \multicolumn{3}{c}{ Risk of damage } \\
\hline $1-2$ & Low & Low & Moderate \\
$3-4$ & Low & Moderate & High \\
5 & High & High & High \\
(from Sw EPA, 2000) & & \\
\hline
\end{tabular}

and Feng (2000). The relevant factors and their weights in the two Hunan catchments are listed in Table 6. BLT is in the most sensitive class with weight 5 , while LKS is highly sensitive (weight 4). This is in general agreement with the results of the SwEPA (2000) scheme (Table 5).

SwEPA (2000) also gives the risk of future damage due to acidifcation at various deposition levels for the soil classes (Table 7)

The annual S-deposition has been estimated as 5-6 gS m $\mathrm{gr}^{-1}$ in the BLT and LKS catchments, i.e. much more than $1.2 \mathrm{gS} \mathrm{m}^{-2} \mathrm{yr}^{-1}$. Considering that the soils are in acidity class 4 and 3, respectively, long-term risk of damage from soil water acidification is high according to this scheme. However, a number of factors complicate the picture. The high deposition of calcium mitigating soil acidification may be the most important. A better indication of potential future acidification may be obtained by including $\mathrm{N}$-compounds and subtract metal base cations in the deposition. Neglecting dry deposition, which is very uncertain, we calculate $\left(\left[\mathrm{SO}_{4}{ }^{2-}\right]+\left[\mathrm{NO}_{3}^{-}\right]+\left[\mathrm{NH}_{4}^{+}\right]\right)-\left(\left[\mathrm{Ca}^{2+}\right]\right.$ $\left.+\left[\mathrm{Mg}^{2+}\right]+\left[\mathrm{Na}^{+}\right]+\left[\mathrm{K}^{+}\right]\right)$in precipitation. Using wet deposition data (Table 3) the difference amounts to

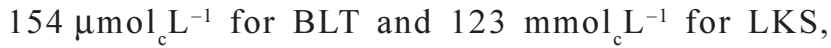
corresponding to depositions of about $240 \mu \mathrm{mol}_{\mathrm{c}} \mathrm{m}^{-2}$ and $170 \mu \mathrm{mol} \mathrm{m}^{-2}$, respectively. If the weathering is less than this, acidification is likely to occur in the long-term. This assumes that ammonium is nitrified and that all nitrate is leached which leads to an overestimation. However, in view of the high nitrate concentrations in streamwater, the approximation seems acceptable. Further, it ignores sulphate retention while the observations indicate significant retention which also contributes to exaggerating acidification before the retention becomes negligible. On the other hand, the calcium deposition may be related in part to anthropogenic emissions; these may be reduced in future so that more acidification than predicted would result. Notwithstanding the high sensitivity and large S-deposition, damage to vegetation has yet to be reported in the two small catchments.

\section{Conclusions}

Sulphur deposition in Hunan Province is high, about $5-6 \mathrm{gS} \mathrm{m}^{2} \mathrm{yr}^{-1}$ at the two sites studied. The deposition of oxidized and reduced nitrogen is also considerable but is probably less than the S-deposition. However, in soil and stream water, the nitrate concentrations are actually higher than the sulphate concentrations on an equivalent basis so $\mathrm{N}$-deposition may play an important role in acidification. Some sulphate is adsorbed in the soils; this may have delayed and is still delaying acidification. So far, no clear signs of damage to vegetation have been documented. However, based on soil pH, base saturation and exchangeable aluminium, there is a risk of ecosystem damage due to acidification particularly in the BLT catchment if the deposition is not reduced. The Ca-deposition in the catchment is high and it seems likely that a considerable contribution is from man-made sources. A reduction in manmade $\mathrm{Ca}$ emission in the future may increase acidification, which would make the situation more serious (Larssen et al., 2001). Other studies have shown that this applies to large areas in southern China. The stream in one of the studied catchments is neutral while average $\mathrm{pH}$ in the stream in the other catchment is about 5. The extent of water acidification in Hunan is not known but other studies have indicated that water acidification is not a serious problem in China. However, further studies, necessary to quantify the potential damage, include investigations in small catchments as described here, regional mapping of sensitive soils and waters, and modelling studies.

Despite its limitations, this study corroborates the need for reductions in sulphur emissions. The goal of a $10 \%$ nation wide reduction and a $20 \%$ reduction in "two controlling zone" from 2000 to 2005 (SEPA, 2002) is a good start but further reductions are probably needed.

\section{Acknowledgements}

This work is financially supported in part by the Chinese Ministry of Education "Comprehensive study of acid deposition and soil acidification in a small catchment near Changsha" (2000 65-HN005). The authors thank Mr. Liu Peng, Ms. Huang Yunxiang, Mr. Zhang Yong and Mr. Zeng Min for collecting and analysing field samples. Dr Thorjorn Larssen is thanked for fruitful discussions and for his valuable comments on the manuscript.

\section{References}

Amann, M., 2001. Emission inventories, emission control options and control strategies: An overview of recent developments. Water Air Soil Pollut., 130, 43-50. 
APHA (American Public Health Association), AWWA, WPCF, 1985. Standard Methods for the Examination of Water and Wastewater, Annual Book of ASTM Standards 16th ed. Washington, DC, USA.

Barnes, R.B., 1975. The determination of specific forms of aluminium in natural water. Chem. Geol. 15, 177-199.

Berggren, D. and Mulder, J., 1995. The role of organic matter in controlling aluminium solubility in acidic mineral soil horizons. Geochem. Acta, 59, 4167-4180.

Bernhardt, E .S., Hall, R.O. and Likens, G.E., 2002. Whole-system Estimates of Nitrification and Nitrate Uptake in Streams of the Hubbard Brook Experimental Forest. Ecosystems, 5, 419-430.

Chen Ming, Tan Jianan and Sun Fuchen, 1993. Research on the mechanisms of $\mathrm{NO}_{3}{ }^{-}$and $\mathrm{SO}_{4}{ }^{2-}$ adsorption in red soil in southern Hunan. Environ. Chem. (in Chinese), 12, 252-257.

Chen Ming, Tan Jianan and Sun Fuchen., 1995. Reseach on the mechanisms of sulfate adsorption in quaternary red soil in southern Hunan. Environ.l Chem. (in Chinese), 14, 129-133.

Christophersen, N., Seip, H.M. and Wright, R.F., 1982. A model for streamwater chemistry at Birkenes, Norway. Water Resour. Res., 18, 977-996.

Cronan, C.S. and Grigal, D.F., 1995. Use of Calcium/Aluminum Ratios as Indicators of Stress in Forest Ecosystems. J. Environ. Qual., 24, 209-226.

Dahlgren, R.A. and Walker, W.J., 1993. Aluminum release rates from selected spodosol BS horizons - effect of $\mathrm{pH}$ and solid state aluminum pools. Geochim. Cosmochim. Acta, 57, 57-66.

Dambrine, E., Probst, A., Viville, D, Biron, P., Paces, T., Novak, M., Buzek. and Cerny, J., 2000. Spatial variability and long term trends in mass balance of $\mathrm{N}$ and $\mathrm{S}$ in central European forested catchments. In: Ecological Studies; Carbon and Nitrogen cycling in European Forested Ecosystems, E.D. Schulze (Ed.), Springer, Dordrecht, Chap. 19, 405-418.

Department of Chemistry Columbus State University, 2000. Precipitation Titrations Mohr Method of Chloride Determination, Quantitative Analysis Lab Manual. Chemistry 2315 (http://patellab.slu.edu/user/sbuckner/homepage)

Driscoll, C.T., 1984. A procedure for the fractionation of aqueous aluminum in dilute acidic waters. Int. J. Environ. Chem., 16, $267-283$.

Driscoll, C.T., Otton, J.K. and Iverfeldt, Å., 1994. In : SCOPE 51, Biogeochemistry of Small Catchments - A Tool for Environmental Research, B. Moldan and J. Cerny, (Eds.) Chapter3:Atmospheric Chemical Input to Small Catchments . Chapter13: Trace Metals Speciation and Cycling. http:// www.icsu-scope.org

Duan Lei, Hao Jiming, Xie Shaodong, Zhou Zhongping and Ye Xuemei., 2002. Determining weathering rates of soils in China. Geoderma, 110, 205-225.

Galloway, J.N., Norton, S.A. and Church, M.R., 1983. Freshwater acidification from atmospheric deposition of sulfuric acid: A conceptual model. Environ. Sci. Technol., 17, 541-545.

GB 7479-87, 1989. Water quality - Determination of ammoniumNessler's reagent colorimetric method. Analysis and monitoring methods for water and wastewater (3rd ed.). Chinese Environmental Sciences Publishing HouseÿBeijing, China (in Chinese),

Gran, G., 1950. Determination of the equivalence point in potentiometric titration. Acta Chem. Scan., 4, 559-577.

Gran, G., 1952. Determination of the equivalence point in potentiometric titration. Part II. Analyst, 77, 661 .

Hao, J., Duan, L. and Xie, S., 1999. Mapping the relative sensitivity of soils to acid deposition in China. Environ. Sci. (in Chinese), 1-5.
Hendershot, W.H. and Duquette, M., 1986. A simple barium chloride method for determining cation exchange capacity and exchangeable cations. Soil Sci. Soc. Amer. J., 50, 605-608.

IMPACTS, 2003. Integrated Monitoring Program on Acidification of Chinese Terrestrial Systems. http://www.impacts.net.cn/

ISO, 1994. Soil quality - Determination of $\mathrm{pH}$. International standard, ISO10390, $5 \mathrm{pp}$.

Jou, A.S.R. and Kamprath, E.J., 1979. Copper chloride as an extractant for estimating the potentially reactive aluminium pool in acid soils. Soil Sci. Soc. Amer. J., 43, 35-38.

Koptsik, G. and Mukhina, I., 1995. Effects of acid deposition on acidity and exchangeable cations in Podzols of the Kola Peninsula. Water Air SoilPollut., 85, 1209-1214.

Koptsik, G. and Koptsik, S., 1995. Critical loads of acid deposition for forest ecosystems in the Kola Peninsula. Water Air Soil Pollut., 85, 2553-2558.

Koptsik, G.N. and Silaeva, E.D., 1996. Buffering capacity of forest litters to acid atmospheric precipitation, Eurasian Soil Sci., 28, 124-136.

Kuylenstierna, J.C.I., Rodhe, H., Cinderby, S. and Hicks, K., 2001. Acidification in developing countries; Ecosystem sensitivity and the critical load approach on a global scale. Ambio, 30, 20-28.

Larssen, T., Xiong, J., Vogt, R.D., Seip, H. M., Liao, B. and Zhao, D., 1998. Studies of soils, soil water and stream water at a small catchment near Guiyang, China. Water Air Soil Pollut., 101, 137-162.

Larssen, T., Seip, H.M., Carmichael, G.R. and Schnoor, J.L., 2001. The importance of calcium deposition in assessing impacts of acid deposition in China. Water Air Soil Pollut., 130, 16351640.

Li, W. and Gao, J., 2002. Acid deposition and integrated zoning control in China. Environ. Manage., 30, 169-182.

Liao, B. and Li, C., 1989. A study on the buffering mechanism of soils. Environ. Sci. (in Chinese), 10, 30-34.

Liao, B., Larssen, T., Seip, H.M. and Vogt, R.D., 1994. Anion adsorption and aluminum release from Chinese soils treated with different concentrations of (NH4) ${ }_{2} \mathrm{SO}_{4}$ and $\mathrm{NH}_{4} \mathrm{NO}_{3}$. J. Ecol. Chem., 3, 281-301.

Liao, B., Seip, H.M.and Larssen, T., 1997. Response of two Chinese forest soils to acidic input: leaching experiment. Geoderma, 75, 53-73.

Liao, B., Larssen, T. and Seip, H.M., 1998. Response of five Chinese forest soils to acidic input: batch experiment. Geoderma, 86, 295-316.

Likens, G.E., Driscoll, C.T., Buso, D.C.,Mitchell, M.J., Lovett, G.M., Bailey, S.W... Siccama, T.G., Reiners, W. A. and Alewell, C., 2002. The biogeochemistry of sulfur at Hubbard Brook. Biogeochemistry 60, 235-316.

Lu, R., 1999. Analyses methods of soil and agricultural chemical. Agricultural Sciences Publishing House, Beijing, China (in Chinese)

Matzner, E. and Prenzel, J., 1992. Acid deposition in the German Solling area: effects on soil solution chemistry and Al mobilization. Water Air Soil Pollut., 61, 221-234.

McKeague, J.A. and Day, J.H., 1966. Dithionite- and oxalateextractable $\mathrm{Fe}$ and $\mathrm{Al}$ as aids in differentiating various classes of soil. Can. J. Soil Sci., 46, 13-22.

Merino, A., Alvarez, E. and Garcia-Rodeja, E., 1994. Response of some soils of Galicia (NW Spain) to $\mathrm{H}_{2} \mathrm{SO}_{4}$ acidification. Water Air Soil Pollut., 74, 89-101.

Neal, C., Smith, C.J., Walls, J., Billingham, P., Hill, S. and Neal, M., 1990, Hydrochemical variations in Hafren forest stream waters, Mid Wales. J. Hydrol., 116, 186-200. 
NEGTAP (The National Expert Group on Transboundary Air Pollution), 2001. Transboundary Air Pollution: Acidification, Eutrophication and Ground-Level Ozone in the UK. The UK NEGTAP report 2001, Chapter 5: effects on soils. (www.emep.int/assessment). 98-110

Nilsson, S.I., Why is Lake Gårdsjon acid? An evaluation of processes contributing to soil and water acidification. Ecol. Bull. (Stockholm), 37, 311-318.

Prietzel, J. and Feger, K.H., 1992. Dynamics of aqueous aluminium species in podzol affected by experimental $\mathrm{MgSO}$ and $\left(\mathrm{NH}_{4}\right)_{2} \mathrm{SO}_{4}$ treatments. Water Air Soil Pollut.. 65, 153-173.

Probst, A., Dambrine, E., Viville, D. and Pritz, B., 1990. Influence of acid atmospheric inputs on surface water chemistry and mineral fluxes in a declining spruce stand within a small granite catchment (Vosges Massif, France). J. Hydrol., 116, 101-124.

Richter, D.D. and Lindberg, S.E., 1988. Incident precipitation and forest canopy throughfall: Analyses of sampling methods. $J$. Environ. Qual., 17, 619-622.

Rodhe, H., Grennfelt, P., Wisniewski, J., Agren, C., Bengtsson, G., Johansson,K., Kauppi, P., Kucera, V., Rasmussen, L., Rosseland., B., Schotte, L. and Selldén, G., 1995. Acid Reign '95-conference summary statement. Water Air Soil Pollut., 85, $1-14$.

Schecher, W. and Driscoll, C.T., 1987. An evaluation of uncertainty associated with aluminum equilibrium calculations. Water Resour. Res., 23, 525-535.

Seip, H.M., Aagaard, P., Angell, V., Eilertsen, O., Larssen, T., Lydersen, E., Mulder, J., Muniz, I.P., Semb, A., Tang, D., Vogt, R.D., Xiao, J., Xiong, J., Zhao, D. and Kong, G., 1999. Acidification in China: Assessment based on studies at forested sites from Chongqing to Guangzhou. Ambio, 28, 522-528.

SEPA, 2000.Report on the state of environment in China (SoE China 000), State Environmental Protection Administration. (http://www.zhb.gov.cn) Atmospheric Environment. p1

SEPA, 2001, Information of Environment (in Chinese), 2001.5.28, 146(9), State Environmental Protection Administration.

SEPA, 2002, The National tenth five-year Plan for Environmental Protection, State Environmental Protection Administration, Beijing, 5pp.

Shao, M., 2002. Acid deposition from IMPACT sites; chemistry and variation. Presentation at IMPACTS Mid-term Conference, Beijing, Nov. 2002. http://www.impacts.net.cn/
Skoog, Holler and Neiman, 1998. Principles of Instrumental Analysis 5th Edition. Harcourt Brace and Co., Orlando, USA . Chapters 7, 13 and 14

Stoddard, J.L., 1991. Trends in Catskill stream water qualityEvidence from historical data : Water Resour. Res. 27, 28552864.

SwEPA, 2000. Acidification of forest land. Swedish Environmental Protection Agency (http://www.internat.environ.se)

Taylor, S.R. and McLennan, S.M., 1985. The Continental Crust: Its Composition and Evolution Blackwell Scientific Publications. Geoscience. Blackwell, Oxford, UK. 312 pp.

Tao Fulu and Feng Zongwei., 2000, Terrstrial ecosystem sensitivity to acid deposition in South China. Water Air Soil Pollut., 118, 231-243

Van Reeuwijk, L.P., (Ed.), 1995. Procedures for Soil Analysis (3rd $e d n$.). ISRIC, Wageningen, The Netherlands, 12-1-8.

Vogt, R.D., Mortensen, T., Mulder, J., Solberg, S. and Aas, W., 2001. Cai Jia Tang (CJT) monitoring site, Hunan province. Catchment Manual, IMPACTS project: Integrated Monitoring Program on Acidification of Chinese Terrestrial Systems. NIVA, Postboks 173, Kjelsås 0411 Oslo, Norway. 29pp. (http// www.waterquality.crc.org.au/nom/Vogt.doc)

Wang, Y.G., Sheng, P.L. and Yuan, D.W., 1989.,Effects of Simulated Acid Rain on Leaching And Availability of Soil Metal Ions. Environ. Sci. (in Chinese), 9, 22--26.

West, A.J., Findlay, S.E.G., Burns, D.A., Weathers, K.C. and Lovett, G.M., 2001. Catchment-scale variation in the nitrate concentrations of groundwater seeps in the Catskill Mountains, New York, USA. Water Air Soil Pollut., 132, 389-400.

Williams, M.W., Yang, D., Liu, F., Turk, J. and Melack, J.M., 1995. Controls on the major ion chemistry of the Urümqi river, Tian Shan, P. R. China. J. Hydrol. 172, 209-229.

Zhao, D., Seip, H. M., Zhao, D.W. and Zhang, D., 1994, Pattern and cause of acidic deposition in the Chongqing region, Sichuan province, China. Water Air Soil Pollut., 77, 27-48.

Zhao, D., Larssen, T., Zhang, D., Gao, S., Vogt, R.D., Seip, H.M. and Lund, O.J., 2001. Acid deposition and acidification of soil and water in the Tie Shan Ping area, Chongqing, China. Water Air Soil Pollut., 130, 1733-1738.

Zimmermann, L. and Zimmermann, F., 2002, Fog deposition to Norway spruce stands at high-elevation sites in the Eastern Erzgebirge (Germany). J. Hydrol. 256, 166-175. 